\title{
Reproduction of Pimelodus maculatus (Siluriformes: Pimelodidae) in three section of Grande River basin, downstream Porto Colombia dam, south-eastern Brazil
}

\author{
Alessandro Loureiro Paschoalini ${ }^{1}$, Violeta da Rocha Perini ${ }^{2}$, Dirceu Marzulo Ribeiro ${ }^{3}$, \\ Paulo Sérgio Formagio ${ }^{3}$, Elizete Rizzo ${ }^{2}$ and Nilo Bazzoli ${ }^{1}$
}

\begin{abstract}
The alterations to the hydrologic regime downstream from hydroelectric dams may cause an impact on the reproductive success of fishes. This study aimed to analyse the influence of the physical and chemical parameters of the water of the Grande and Pardo Rivers on gonadal maturation, oocyte diameter, follicular atresia and biological indices of Pimelodus maculatus collected from three river sections: Grande River, downstream from the Porto Colômbia dam (S1), Grande River, downstream from the confluence with the Pardo River (S2) and in the Pardo River channel (S3). Males and females captured in S1 presented significantly higher average values for total length and body weight than those captured in S2 and S3. The gonadosomatic index values were significantly higher in fish collected in S3 and the Fulton condition factor did not show significant differences in fish collected from the three sections. The oocyte diameter, the follicular cells height and the zona pellucida thickness did not show any statistical differences between the sections. Conductivity presented a significant difference between S1 and S3 and during the reproductive period, water transparency presented similar values in the two sampling sections of the Grande River, but a much lower value in the Pardo River. A low frequency of fish with reproductive activity was registered in S1, whereas in S2 and S3 higher frequencies were recorded, emphasising the need of preserving the tributaries for the reproductive success of P. maculatus of the Grande River in south-eastern Brazil.
\end{abstract}

A jusante das barragens hidrelétricas ocorrem alterações no regime hidrológico que podem causar impactos sobre o processo reprodutivo dos peixes. O objetivo do presente estudo foi analisar a influência de parâmetros físico-químicos da água do rio Grande e rio Pardo sobre a maturação gonadal, diâmetro ovocitário, atresia folicular e índices biológicos de Pimelodus maculatus coletados em três trechos: a jusante do reservatório de Porto Colômbia (P1), a jusante da confluência do rio Grande com rio Pardo (P2) e na calha do rio Pardo, a aproximadamente $100 \mathrm{~km}$ de P2 (P3). Machos e fêmeas capturados no ponto 1 apresentaram valores médios de comprimento total e peso corporal significativamente maiores do que aqueles capturados nos pontos 2 e 3 . Os valores de IGS foram significativamente maiores nos peixes coletados no ponto 3 e o fator de condição de Fulton não apresentou diferenças significativas entre os peixes coletados nos três pontos. O diâmetro ovocitário, a altura das células foliculares e a espessura da zona pelúcida dos ovócitos vitelogênicos não mostraram diferenças estatísticas entre os pontos. A condutividade apresentou diferença significativa entre os pontos 1 e 3 e a transparência da água durante o período reprodutivo apresentou valores próximos nos dois pontos amostrais do rio Grande, e valor bem menor no ponto amostral do rio Pardo. Em P1 registrou-se baixa frequência de peixes em atividade reprodutiva, e em P2 e P3 maiores frequências de peixes reproduzindo. Os resultados encontrados enfatizam a necessidade de conservação de tributários para o sucesso reprodutivo de P. maculatus, do rio Grande no sudeste do Brasil.

Key words: Abiotic factors, Dam impacts, Environmental impacts, Gonadosomatic index.

\section{Introduction}

Several physical and chemical factors affect the behaviour and the reproduction of freshwater fishes, such as: water temperature, rainfall, turbidity, feeding, water level, xenobiotic agents, environmental stress, photoperiod, and population density (Janz et al., 2001; Weber et al., 2002). Water temperature and rainfall are critical factors which trigger spawning migration and, therefore, the reproductive success of a species may be related to temperature and an increase in water volume (Parkinson et al., 1999; Rizzo et al., 2003).

${ }^{1}$ Pontifícia Universidade Católica de Minas Gerais, Programa de Pós-Graduação em Zoologia de Vertebrados. Av. Dom José Gaspar, 500, 30535-610 Belo Horizonte, MG, Brazil. bazzoli@pucminas.br (NB)

${ }^{2}$ Universidade Federal de Minas Gerais, Departamento de Morfologia, Instituto de Ciências Biológicas. Av. Antônio Carlos, 6627, 30161 -

970 Belo Horizonte, MG, Brazil

${ }^{3}$ Estação de Hidrobiologia e Piscicultura de Furnas, UHE Furnas. Rua Lavras, 288, 37943-000, Furnas, MG, Brazil. 
Alterations to the hydrologic regime downstream from hydroelectric dams, such as a decrease in the flood peaks, may result in unstable thermal and hydrologic conditions (Baxter, 1977; Agostinho et al., 1992). Such impacts seem to especially affect the reproductive process of neotropical fish since, in tropical regions, the flood regime is considered to be critical for trigging reproduction and spawning migration (Sato et al., 2003). Therefore, several impacts are reported relating to fish communities downstream from dams, such as a change in the ichthyofauna's composition before and after the dam, interruption of the migration process, reproduction inhibition, facility to introduce exotic species, changes in behaviour, immobilisation and death, an increase in vulnerability to predation, interference in feeding areas and juvenile recruitment (Welcomme, 1979; Ruane et al., 1986; Agostinho et al., 1993; Sato et al., 2003). In the Paraná River, Brazil, the reproductive behaviour of migratory fish was altered in the first kilometres after the Itaipu dam, where fish could not spawn, and thus presented an intensive process of follicular atresia (Agostinho et al., 1993). Likewise, the colder water released by the dams of the Colorado River, in the USA, resulted in a decline of the local ichthyofauna (Paukert \& Rogers, 2004).

The so called mandi-amarelo, Pimelodus maculatus Lacepède, 1803 , is considered by some authors to be a migratory species, requiring shorter sections of rivers in which to reproduce, differing from other neotropical migratory fishes which migrate for long distances (Agostinho et al., 2003). This fish represents an important species, both for commercial and recreational fishing (Lundberg \& Littmann, 2003) and some studies on this species have been performed in the Paraná River basin (Dei Tos et al., 2002; Maia et al., 2007). Considering that there are no studies analysing the importance of tributaries for the reproduction of the mandi-amarelo in the area influenced by the Porto Colômbia dam, the objective of the study was to comparatively analyse the reproduction of P. maculatus in the Grande River, downstream from the Porto Colômbia dam, and its tributary, the Pardo River, in south-eastern Brazil.

\section{Materials and Methods}

Study site and Fish. The Porto Colômbia dam is located in middle third of the Grande River, between the municipalities of Planura (Minas Gerais State) and Colômbia (São Paulo State), in south-eastern Brazil. The samples were obtained bimonthly from three sections of the Grande River basin, between January/2010 and February/2011. The first section was located in the Grande River, immediately downstream from the Porto Colômbia dam (S1) (2007'44"S 4834'34'W), the second section, downstream from the confluence of the Grande River and the Pardo River (S2) (20 $0^{\circ} 10^{\prime} 04^{\prime \prime}$ S $\left.48^{\circ} 38^{\prime} 44^{\prime \prime} \mathrm{W}\right)$, and the third, in the channel of the Pardo River (S3) (20 81'48'S $48^{\circ} 23^{\prime} 41^{\prime \prime W}$ ) (Fig. 1). The fish were captured by fishermen from FURNAS Centrais Elétricas S/A, using gillnets $(6 \mathrm{~cm}$ mesh size $)$ and casting nets $(6 \mathrm{~cm}$ mesh size $)$ with the same effort between the sites. The animals were sacrificed by crosssection of the cervical medulla in accordance with the Animal
Experimentation Guidelines, established by the Brazilian College of Animal Experimentation (COBEA). For all specimens, we registered the following biometric data: total length (TL), standard length (SL), body weight (BW) and gonad weight $(\mathrm{GW})$. From the biometric data obtained, we calculated the gonadosomatic index $\left(\mathrm{GSI}=\mathrm{GW} / \mathrm{BW}^{*} 100\right)$ and the Fulton condition factor $\left(\mathrm{K}=\mathrm{BW} \times 100 / \mathrm{SL}^{3}\right)$. Voucher specimens were sent to Natural Sciences Museum of Pontifícia Universidade Católica de Minas Gerais, Brazil (MCNI-0507).

Histology, gonadal maturation stages and follicular diameter. Gonad fragments were fixed in Bouin's fluid for 8 to 12 hours, kept in alcohol $70 \%$ and were submitted to the routine histological techniques: paraffin embedding, 3-5 $\mu \mathrm{m}$ thick microtomy sections, and haematoxylin and eosin stain (HE). The gonadal maturation stages were established based on the oocyte distribution, spermatogenic lineage cells, and variations of the GSI (Santos et al., 2004; Carvalho et al., 2009; Arantes et al., 2010). The diameter of the vitellogenic follicles (follicular cells, zona pellucida and oocyte) was determined from histological slides of the mature ovaries using a micrometric ocular attached to a light microscope.

Fecundity. In order to estimate fecundity, samples from the middle region of the mature ovaries were fixed in a modified Gilson's solution ( $100 \mathrm{ml}$ of alcohol $60 \%, 880 \mathrm{ml}$ of distilled water, $15 \mathrm{ml}$ of nitric acid $80 \%, 18 \mathrm{ml}$ of glacial acetic acid and

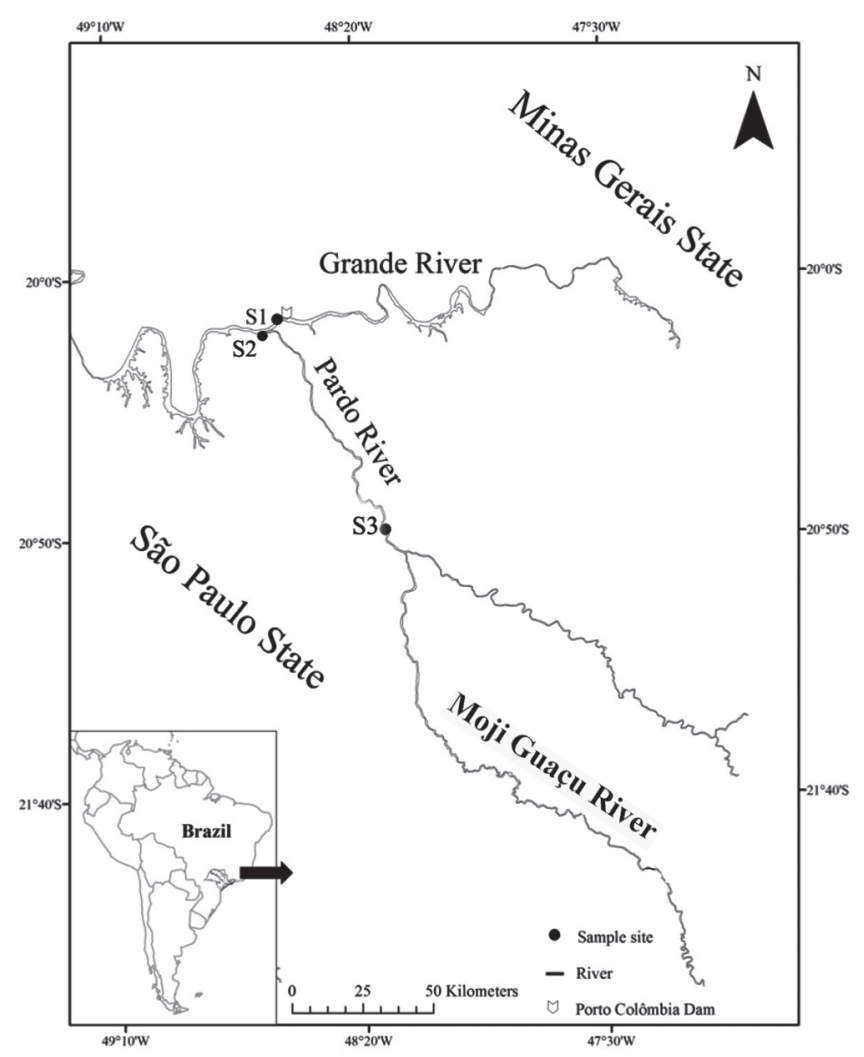

Fig. 1. Study area with indication of the sample sections. 
$20 \mathrm{~g}$ of mercury chloride) until complete dissociation of the follicles had occurred. The vitellogenic follicles were separated from the others by the use of sieves whose meshes presented a diameter smaller than the minimum diameter of the vitellogenic oocytes. Absolute fecundity (Af) was determined from the following expression: $\mathrm{Af}=\mathrm{NFG} . \mathrm{GW}$; where $\mathrm{NFG}=$ number of follicles per ovary gram and $\mathrm{GW}=$ gonad weight. The relative fecundity ( $R F$ ) was calculated in order to eliminate the interference of body weight $(\mathrm{BW})$ on the fecundity estimates, using the expression: $\mathrm{RF}=\mathrm{Af} / \mathrm{BW}$.

Physical and chemical parameters of the water. Amultiparameter surface probe (YSI brand) was used for measuring the following physical and chemical parameters of the water: temperature, dissolved oxygen concentration, $\mathrm{pH}$ and electrical conductivity. The water transparency was measured with a Secchi disc.
Statistical Analysis. All results were expressed as means \pm standard deviation and were considered significant with $p<0.05$. The comparison of follicular diameters, morphometric measurements, abiotic factors and biological indices of the three river sections were done through the Kruskal-Wallis non-parametric test followed by the Dunn post-test. For all tests, a degree of freedom of $\mathrm{H}=2$ was obtained.

\section{Results}

Morphologically, the ovaries of the P. maculatus are sacciform in shape, yellow in colour and the testes are elongated organs with filiform projections containing anastomosed seminiferous tubules. In the caudal region of the testes in advanced maturation/ mature and spent stages, the lumen of the seminiferous tubules presented globular acidophilic secretions (Fig. 2).

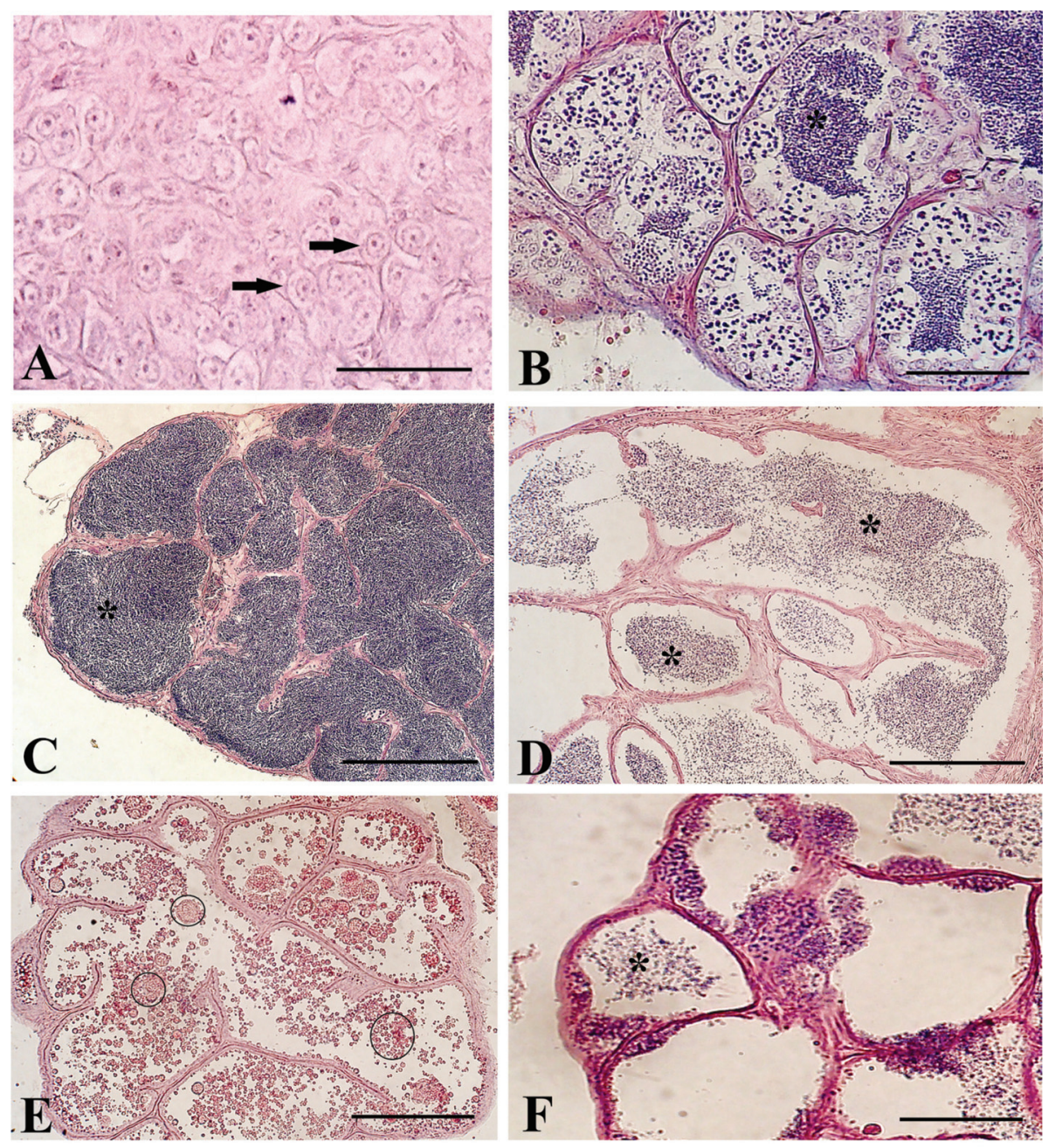

Fig. 2. Histological sections of $P$. maculatus testes, in different stages of gonadal maturation, stained with HE. A: Resting with seminiferous tubules closed containing only spermatogonia; B: Initial maturation, with seminiferous tubules containing all spermatogenic lineage cells and a small amount of sperm; $\mathbf{C}$ : Advanced maturation/mature, with seminiferous tubules filled with sperm; D: Partially spent, with open seminiferous tubules containing a considerable amount of sperm; E: Caudal region of a partially spent testis with globular acidophilic secretion (circle); F: fully spent, with open seminiferous tubules containing residual sperm in the lumen. ${ }^{*}=$ Sperm; Arrow $=$ Spermatogonia. Scale bars $=20 \mu \mathrm{m}(\mathbf{A}), 50 \mu \mathrm{m}(\mathbf{B}$ and $\mathbf{F}), 100 \mu \mathrm{m}(\mathbf{C}-\mathbf{E})$. 
A total of 302 females and 254 males $(\mathrm{N}=556)$ specimens of $P$. maculatus were captured from the three sections. Males and females captured from S1 presented average values of total length and body weight higher than those captured in S2 and S3. The GSI values were significantly higher in fish collected in $\mathrm{S} 3$ and the Fulton condition factor did not show significant differences in fish collected in the three sections (Tables 1-2).

Through macro and microscopic analyses of the gonads and GSI variations, four gonadal maturation stages were determined: $1=$ resting, $2=$ initial maturation, $3=$ advanced maturation/mature and $4=$ spawned for females and spent for males (Figs. 2-3). During the whole sampling period, there was a predominance of resting females in the three sections and of resting males in S1. Males and females in stages M3 and F3 were recorded in the three sampling sections although females in that stage were rare. Spawned females (F4) were only registered in S3, whereas spent males (M4) were found in all three sections (Fig. 4). The highest values for absolute fecundity and GSI were recorded in S2 and S3 (Tables 1-2). The oocyte diameter, the follicular cells height and the zona pellucida thickness did not show any statistical differences between the sampling sections (Table 3 ). Despite the low number of spawned females, we observed atretic follicles in the ovaries of females captured in S3. This process was characterised by the fragmentation of the zona pellucida, liquefaction of the yolk, hypertrophy of the follicular cells and yellow body formation. Three phases of follicular atresia were determined in P. maculatus: $1=$ initial, 2 = intermediate, $3=$ final (Fig. 3 ).

Among the chemical and physical parameters of the water, there were no statistical differences between the three sections regarding the $\mathrm{pH}$, dissolved oxygen concentration and temperature (Fig. 5). In all three sections, the temperature was higher from October to March. The conductivity presented the highest values in S3 and the lowest ones in S1, with statistically significant differences between them. The conductivity peak in $\mathrm{S} 2$ and $\mathrm{S} 3$ occurred in October, followed by a gradual decrease until February, during the reproductive period. Water transparency in the reproductive period, from November to January, presented similar values from the two sampling sections of the Grande River $(\mathrm{S} 1=2.45 \pm 0.05 \mathrm{~m}, \mathrm{~S} 2=2.35 \pm 0.05 \mathrm{~m})$, and a much smaller value in the Pardo River site $(\mathrm{S} 3=0.22 \pm 0.02 \mathrm{~m})$.

\section{Discussion}

This study showed that the construction of the Porto Colômbia dam on the Grande River resulted in alterations to the reproduction process of $P$. maculatus, in the section downstream from the dam, and that the Pardo River is an important tributary for reproductive success of this species.

Table 1. Biological variables of $P$. maculatus males, collected between January/2010 and February 2011, from three different sections of the Grande River basin, downstream from the Porto Colômbia power plant. Section 1: Grande River, downstream from the Porto Colômbia power plant; Section 2: confluence of the Grande and Pardo rivers; Section 3: the Pardo River channel; N: number of fishes captured; GSI: Gonadosomatic index; K: Fulton condition factor. Data expressed as mean \pm standard deviation (SD); different letters indicate statistical differences between the sampling sections $(\mathrm{p}<0.05)$.

\begin{tabular}{lcccccc}
\hline & \multicolumn{2}{c}{ Section 1 $(\mathrm{N}=70)$} & \multicolumn{2}{c}{ Section 2 $(\mathrm{N}=81)$} & \multicolumn{2}{c}{ Section 3 $(\mathrm{N}=101)$} \\
\cline { 2 - 7 } & Mean \pm SD & Range & Mean \pm SD & Range & Mean \pm SD & Range \\
\hline TL $(\mathrm{cm})$ & $27.51 \pm 2.25 \mathrm{a}$ & $23-33.6$ & $25.42 \pm 2.53 \mathrm{~b}$ & $20-33$ & $26.31 \pm 2.60 \mathrm{c}$ & $16.5-33.5$ \\
BW $(\mathrm{g})$ & $254.59 \pm 78.8 \mathrm{a}$ & $140-527$ & $217.51 \pm 60.22 \mathrm{~b}$ & $115-415$ & $238.48 \pm 72.63 \mathrm{a}$ & $52-533$ \\
GSI (\%) & $0.17 \pm 0.13 \mathrm{a}$ & $0.004-0.54$ & $0.29 \pm 0.10 \mathrm{~b}$ & $0.10-0.58$ & $0.33 \pm 0.26 \mathrm{~b}$ & $0.003-1.01$ \\
K & $2.12 \pm 0.42 \mathrm{a}$ & $1.18-4.33$ & $2.40 \pm 0.40 \mathrm{a}$ & $1.69-4.39$ & $2.28 \pm 0.40 \mathrm{a}$ & $1.15-3.25$ \\
\hline
\end{tabular}

Table 2. Biological variables of $P$. maculatus females, collected between January/2010 and February 2011, from three different sections of the Grande River basin, downstream from the Porto Colômbia power plant. Section 1: Grande River, downstream from the Porto Colômbia power plant; Section 2: confluence of the Grande and Pardo rivers; Section 3: the Pardo River channel; N: number of fishes captured; n: number of mature ovaries; GSI: Gonadosomatic index; K: Fulton condition factor; Af: Absolute fecundity; RF: Relative fecundity. Data expressed as mean \pm standard deviation (SD); different letters indicate statistical differences between the sampling sections $(p<0.05)$.

\begin{tabular}{lcccccc}
\hline & \multicolumn{2}{c}{ Section 1 $(\mathrm{N}=140)$} & \multicolumn{2}{c}{ Section 2 $(\mathrm{N}=66)$} & \multicolumn{2}{c}{ Section 3 $(\mathrm{N}=96)$} \\
\cline { 2 - 7 } & Mean \pm SD & Range & Mean \pm SD & Range & Mean \pm SD & Range \\
\hline TL $(\mathrm{cm})$ & $30.34 \pm 3.10 \mathrm{a}$ & $23.0-39.0$ & $27.98 \pm 3.72 \mathrm{bc}$ & $14.5-39.0$ & $29.65 \pm 2.49 \mathrm{ac}$ & $24.0-36.0$ \\
BW $(\mathrm{g})$ & $364.57 \pm 125.04 \mathrm{a}$ & $168-935$ & $296.69 \pm 125.6 \mathrm{bc}$ & $38-873$ & $350.73 \pm 88.8 \mathrm{ac}$ & $178-587$ \\
GSI $(\%)$ & $0.74 \pm 0.36 \mathrm{a}$ & $0.22-2.25$ & $1.18 \pm 1.13 \mathrm{ac}$ & $0.31-4.62$ & $1.30 \pm 1.42 \mathrm{bc}$ & $0.36-7.55$ \\
K & $2.16 \pm 0.34 \mathrm{a}$ & $1.49-3.85$ & $2.31 \pm 0.33 \mathrm{a}$ & $1.49-2.89$ & $2.29 \pm 0.31 \mathrm{a}$ & $1.55-3.2$ \\
Af $(\mathrm{n}=12)$ & $25136 \pm 1259.7 \mathrm{a}$ & $9038-26812$ & $45763 \pm 1377.6 \mathrm{~b}$ & $7274-47289$ & $27095 \pm 6731.9 \mathrm{a}$ & $17165-62857$ \\
RF & $47.40 \pm 7.56 \mathrm{a}$ & $40.9-55.7$ & $93.66 \pm 58.78 \mathrm{a}$ & $27.98-167.1$ & $75.38 \pm 35.04 \mathrm{a}$ & $31.55-125.72$ \\
\hline
\end{tabular}



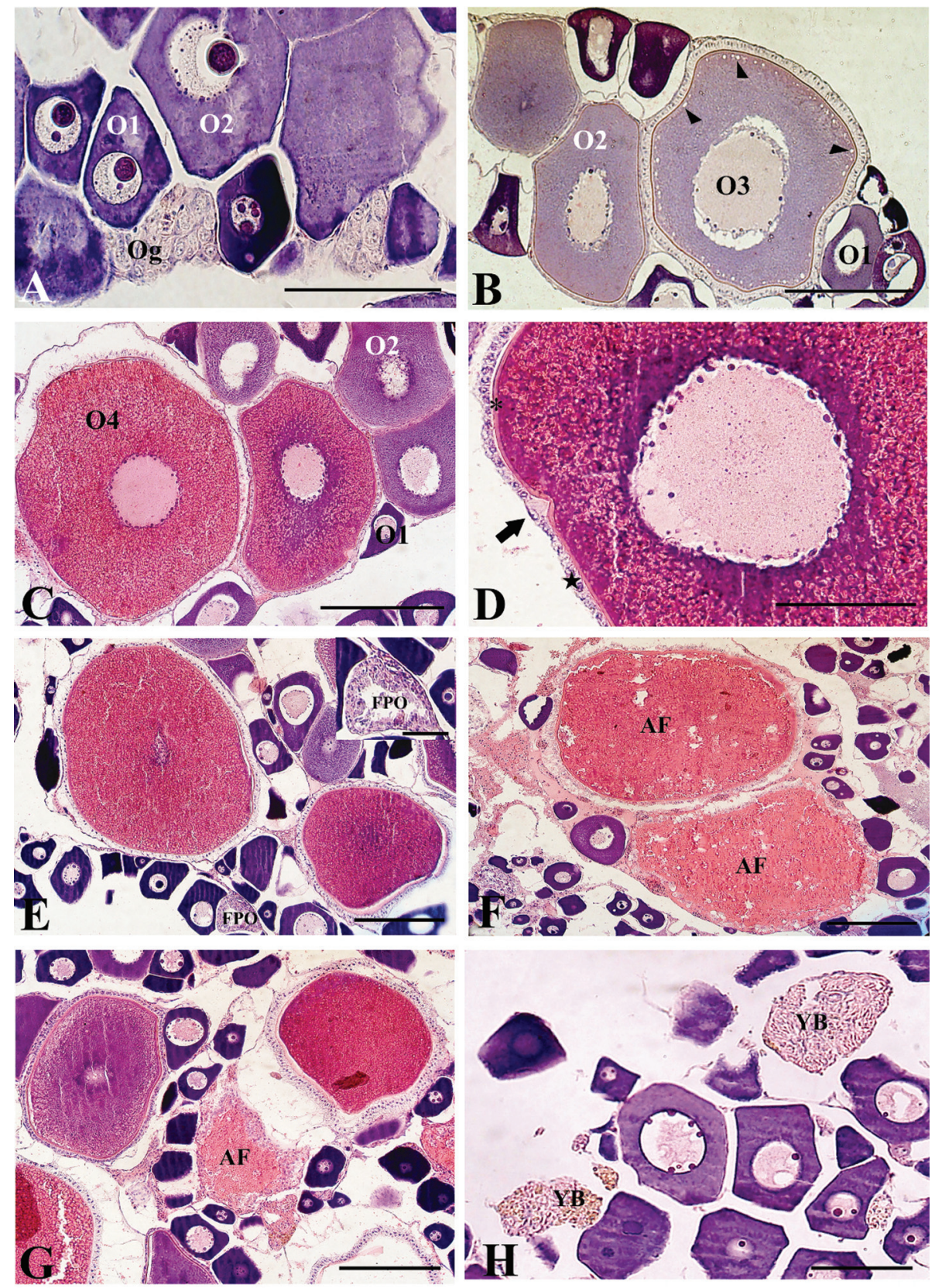

Fig. 3. Histological sections of $P$. maculatus ovaries, in different stages of gonadal maturation, stained with HE. A: Resting, with oogonia nests $(\mathrm{Og})$, initial perinucleolar oocyte $(\mathrm{O} 1)$ with basophilic cytoplasm and advanced perinucleolar follicles (O2) with granular cytoplasm; B: Initial maturation, with $\mathrm{O} 1, \mathrm{O} 2$ and pre-vitellogenic oocyte (O3) presenting cortical alveoli (arrow head) in the peripheral ooplasm; $\mathbf{C}$ : Advanced maturation/mature with $\mathrm{O} 1, \mathrm{O} 2$ and $\mathrm{O} 3$ and vitellogenic oocytes with ooplasm filled with acidophilic yolk globules; D: Detail of vitellogenic oocyte with cubic follicular cells (star), thin zona pellucida (*) and funnel-shaped micropile (arrow); E: Partially spawned, with O1, O2, O3, O4 and postovulatory follicles (FPO); insert of post-ovulatory follicle with wide lumen and wall of follicular cells and theca; F: Atretic follicles (AF) in the initial phase with yolk liquefaction and fragmentation of the zona pellucida; G: Partially spawned ovary with atretic follicle (AF) in the intermediate phase with hypertrophy of the follicular cells and an almost fully reabsorbed yolk; $\mathrm{H}$ : Fully spawned ovary with O1, O2 and atretic follicle in the final stage, forming yellow bodies (YB). Scale bars $=50 \mu \mathrm{m}(\mathrm{A}, \mathrm{D}$, insert of POF and H), $100 \mu \mathrm{m}(\mathrm{B}, \mathrm{C}), 200 \mu \mathrm{m}(\mathrm{E}-\mathrm{G})$. 

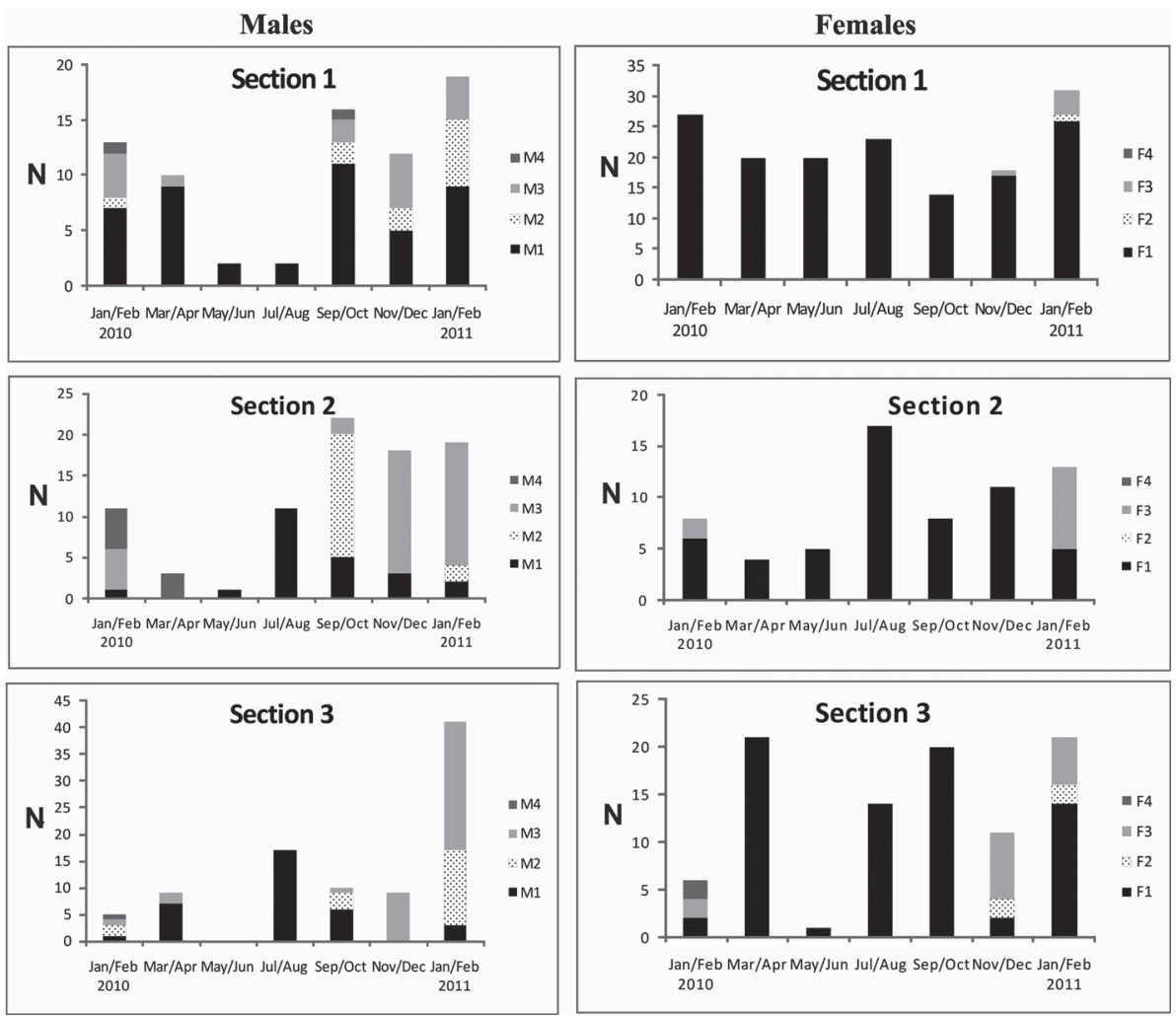

Fig. 4. Bimonthly frequency of the gonadal maturation stages of $P$. maculatus males and females from three sampling sections of the Grande River basin, downstream from the Porto Colômbia dam. Section 1: Grande River, downstream from the Porto Colômbia dam; Section 2: confluence of the Grande and Pardo Rivers; Section 3: the Pardo River channel.

In this study, fish in $\mathrm{S} 1$ presented statistically higher body weight and total length averages than the ones in S2 and S3. This may be explained by the fact that the area immediately downstream from the Porto Colômbia dam, a length of approximately 500 meters, is a protection area, where fishing is completely prohibited and, therefore, favouring a larger size for those fish that remain there. In the other areas of the Grande River and in the Pardo River, there is intensive commercial and recreational fishing, and P. maculatus is one of the most captured species, thus preventing growth as in S1, similar to Bianchi et al. (2000) who found that fish communities subjected to intense fishing pressure tends to be smaller sized.
The morphological features of the fish ovaries and testes captured in the three sampling sections were similar. The yellowish colour of the ovaries and the histological features of the follicular cells and zona pellucida of the vitellogenic oocytes are similar to what has been reported by Melo et al. (2011). The funnel-shaped micropyle observed in P. maculatus in this study seems to be a common pattern for fish of the Pimelodidae family (Rizzo et al., 2002). In this study, anastomosis of the seminiferous tubules, a characteristic of testes of the anastomotic tubular type as described by Parenti \& Grier (2004), was observed. In the caudal portion of the spent testes of P. maculatus,

Table 3. Measurements of P. maculatus vitellogenic follicles from the three sampling sections. Section 1: Grande River, downstream from the Porto Colômbia power plant; Section 2: confluence of the Grande and Pardo rivers; Section 3: the Pardo River channel. N: number of follicles analysed. Data expressed as mean \pm standard deviation (SD); different letters indicate statistical differences between the sampling sections $(\mathrm{p}<0.05)$.

\begin{tabular}{lcccccc}
\hline & \multicolumn{2}{c}{ Section 1 $(\mathrm{N}=20)$} & \multicolumn{2}{c}{ Section 2 $(\mathrm{N}=20)$} & \multicolumn{2}{c}{ Section 3 $(\mathrm{N}=40)$} \\
\cline { 2 - 7 } & Mean $\pm \mathrm{SD}$ & Range & Mean \pm SD & Range & Mean \pm SD & Range \\
\hline Oocyte diameter $(\mu \mathrm{m})$ & $429.7 \pm 53.7 \mathrm{a}$ & $337.8-518.1$ & $446.3 \pm 70.7 \mathrm{a}$ & $263-563.3$ & $457.5 \pm 62.5 \mathrm{a}$ & $351.2-547.8$ \\
Follicular cells $(\mu \mathrm{m})$ & $15.01 \pm 3.40 \mathrm{a}$ & $9.60-21.50$ & $26.18 \pm 12.47 \mathrm{a}$ & $11.90-40.30$ & $18.13 \pm 7.41 \mathrm{a}$ & $7.20-35.00$ \\
Zona pellucida $(\mu \mathrm{m})$ & $2.63 \pm 0.46 \mathrm{a}$ & $1.80-3.50$ & $2.54 \pm 0.73 \mathrm{a}$ & $1.60-4.00$ & $2.81 \pm 0.62 \mathrm{a}$ & $1.70-4.10$ \\
\hline
\end{tabular}



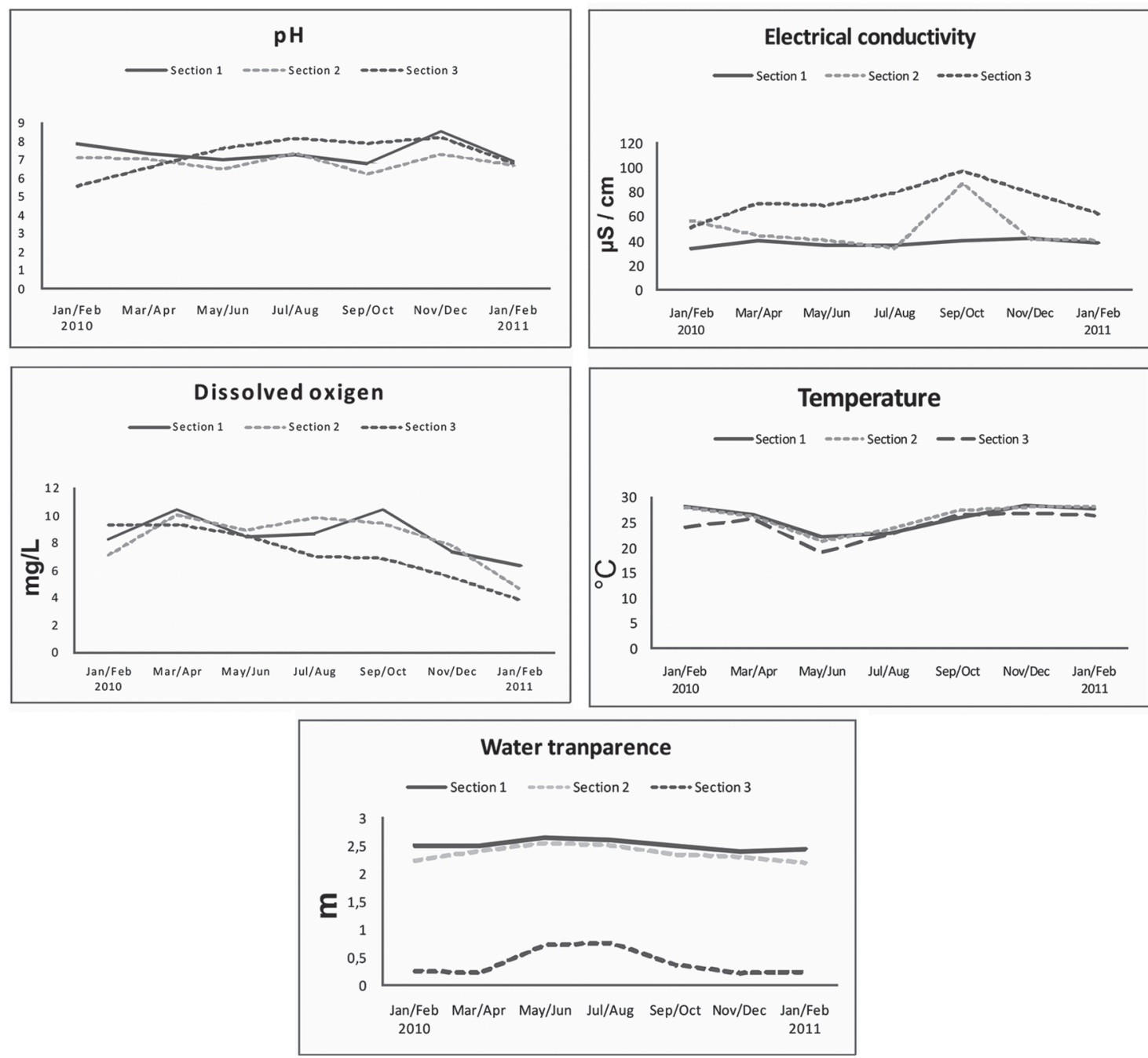

Fig. 5. PH, dissolved oxygen, electrical conductivity, temperature and water transparency in three sections of the Grande River basin, downstream from the Porto Colômbia dam. Section 1: Grande River, downstream from the Porto Colômbia dam; Section 2: confluence of the Grande and Pardo Rivers; Section 3: the Pardo River channel.

globular acidophilic secretion was observed, as has also been observed by Melo et al. (2011). Some studies showed that this secretion may be related to sperm maturation and nutrition and may play a crucial role in fertilisation (Mazzoldi et al., 2005; Chowdhury \& Joy, 2007).

In this study, we observed that the P. maculatus reproduces between October and February, which coincides with the rainy season, confirming the observations of Braga (2000). The low variation of the Fulton condition factor in the three sampling sections suggests that the fish's health is not affected by the reproductive period. A similar result was found for this same species in the Piracicaba River, São Paulo State, by Lima-Junior \& Goitein (2006). Analysing only the reproductive period, from October to February, it was observed that $P$. maculatus presented a low frequency of fish in reproductive activity $(19.70 \%)$ from $\mathrm{S} 1$, whereas in $\mathrm{S} 2$ and $\mathrm{S} 3$, higher frequencies, $56.25 \%$ and
$55.55 \%$ respectively, were registered. A similar situation was observed with fish captured during the reproductive period from the São Francisco River, downstream from the Três Marias dam (Sato et al., 2005).

Impacts on the ichthyofauna downstream from dams have been reported by several authors (Agostinho et al., 1993; Clarkson et al., 2000; Paukert \& Rogers, 2004; Todd et al., 2005; Olden \& Naiman, 2010). A recent study showed that, in the São Francisco River immediately downstream from the Três Marias dam, the species Prochilodus argenteus presented high rates of vitellogenic oocyte atresia and alterations to the endocrine system due to the physical and chemical changes of the water, especially the colder water temperature of this river section (Arantes et al., 2010). Contrarily, in the present study, the mean water temperature in the three sections was not statistically different, thus this is probably not the cause of the low frequency of fish in 
reproductive activity immediately downstream from the Porto Colômbia dam.

In this study, it was verified that in S3, during the reproductive period, there is a sharp decrease in conductivity and water transparency values, indicating that this decrease may act as a reproductive trigger for $P$. maculatus. This assumption is borne out by Godoy's (1972) reports who also observed in the Grande/Pardo/Moji Guaçu Rivers system a decrease in conductivity and transparency during the reproductive period and considered them to be critical factors for triggering fish reproduction. Even though spent/spawned fish were captured from the Pardo River, the small number of fish in these stages, in relation to the total number of collected fish, leads us to believe that $\mathrm{S} 3$ is not a reproduction site, and may only be a migratory route for fish which spawn in the Moji Guaçu River, as described by Godoy $(1967,1972)$.

In S1, a low frequency of mature and spawned/spent fish was observed. Furthermore, a significantly lower GSI and significantly higher body weight was observed when compared to $\mathrm{S} 2$ and $\mathrm{S} 3$. These findings may be related to the environmental parameters after dams which are not favourable to the reproductive success of fish (Olden \& Naimam, 2010). On the other hand, the higher number of mature and spawned/spent fish captured in S2 and S3 reinforces the idea that $P$. maculatus, in its reproductive migration, makes this potamodromous movement between the Grande, Pardo and Moji Guaçu Rivers up to Cachoeira

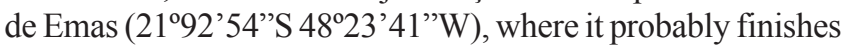
its reproductive migration (Godoy 1967, 1972).

It is known that the construction of dams harms the aquatic biota (Agostinho et al., 1993; Sato et al., 2003; Sato et al., 2005; Arantes et al., 2010; Barletta et al., 2010), thus emphasising the importance of tributaries on the reproductive process since these water bodies may present a natural hydrological system and abiotic factors still unaltered by anthropic action, or within a tolerable threshold for the maintenance of the local biota (Antonio et al., 2007). Therefore, our results emphasise the need to preserve the Pardo and Moji Guaçu Rivers for the reproductive success of $P$. maculatus, since that rivers has a crucial hole in the reproductive migration of this species downstream Porto Colômbia dam.

\section{Acknowledgments}

The authors thank the Hydrobiology and Hatchery Station of FURNAS Centrais Elétricas S/A and to the Brazilian agencies CNPq, CAPES and FAPEMIG for their financial support.

\section{Literature Cited}

Agostinho, A. A., H. F. Júlio jr. \& J. R. Borghetii. 1992. Considerações sobre os impactos dos represamentos sobre a ictiofauna e medidas para sua manutenção. Um estudo de caso: reservatório de Itaipu. Revista Unimar, 14: 89-107.
Agostinho, A. A., V. P. Mendes, H. T. Suzuki \& C. Canzi. 1993. Avaliação da atividade reprodutiva da comunidade de peixes dos primeiros quilômetros a jusante do reservatório de Itaipu. Revista Unimar, 15: 175-189.

Agostinho, A. A., L. C. Gomes, H. I. Suzuki, H. F. Júlio Jr. 2003. Migratory fishes of the Upper Paraná River basin, Brazil. Pp. 19-98. In: Carolsfeld, Y., B. Harvey, C. Ross \& A. Baer (Eds.). Migratory fishes of South America: biology, fisheries and conservation status. Ottawa, International Development Centre/ The World Bank.

Antonio, R. R., A. A. Agostinho, F. M. Pelicice, D. Baily, E. K. Okada, J. H. O. Dias. 2007. Blockage of migration routes by dam construction: can migratory fish find alternative routes? Neotropical Ichthyology, 5: 177-184.

Arantes, F. P., H. B. Santos, E. Rizzo, Y. Sato \& N. Bazzoli. 2010. Profiles of sex steroids, fecundity, and spawning of Curimatapacu Prochilodus argenteus in the São Francisco River, downstream from Três Marias dam, Southeastern Brazil. Animal Reproduction Science, 118: 330-336.

Barletta, M., A. J. Jaureguizar, C. Baigun, N. F. Fontoura, A. A. Agostinho, V. M. F. Almeida-Val, A. L. Val, R. A. Torres, L. F. Jimenes-Segura, T. Giarrizzo, N. N. Fabré, V. S. Batista, C. Lasso, D. C. Taphorn, M. F. Costa, P. T. Chaves, J. P. Vieira \& M. F. M. Corrêa. 2010. Fish and aquatic habitat conservation in South America: a continental overview with emphasis on neotropical systems. Journal of Fish Biology, 76: 2118-2176.

Baxter, R. M. 1977. Environmental effects of dams and impoundments. Annual Review of Ecology and Systematics, 8: 255-283.

Bianchi, G., H. Gislason, K. Graham, L. Hill, X. Jin, K. Korateng, S. Manickchand-Heileman, L. Payá, K. Sainsbury, F. Sanchez \& K. Zwanenburg. 2000. Impact of fishing on size composition and diversity of demersal fish communities. ICES Journal of Marine Science: Journal du Conseil, 57: 558-571.

Braga, F. M. S. 2000. Biologia e pesca de Pimelodus maculatus (Siluriformes, Pimelodidae), no reservatório de Volta Grande, rio Grande (MG-SP). Acta Limnologica Brasiliensia, 12: 1-14.

Carvalho, P. A., A. L. Paschoalini, G. B. Santos, E. Rizzo \& N. Bazzoli. 2009. Reproductive Biology of Astyanax fasciatus (Pisces: Characiformes) in a reservoir in southeastern Brazil. Journal of Applied Ichthyology, 25: 306-313.

Chowdhury, I. \& K. P. Joy. 2007. Seminal vesicle and its role in the reproduction of teleosts. Fish Physiology and Biochemistry, 33: 383-398.

Clarkson, R. W., M. R. Childs \& S. A. Schaefer. 2000. Temperature effects of hypolimnial-release dams on early life stages of Colorado River basin big-river fishes. Copeia, 2000: 402-412.

Dei Tos, C., G. Barbieri, A. A. Agostinho, L. C. Gomes \& H. I. Suzuki. 2002. Ecology of Pimelodus maculatus (Siluriformes) in the Corumbá reservoir, Brazil. Cybium, 26: 275-282.

Godoy, M. P. 1967. Dez anos de observações sobre a periodicidade migratória de peixes do rio Mogi guassu. Revista Brasileira de Biologia, 27: 1-12.

Godoy, M. P. 1972. Brazilian tagging experiments, fishes migration, and upper Paraná River basin eco-system. Revista Brasileira de Biologia, 32: 473-484.

Janz, D. M., M. E. McMaster, L. P. Weber, K. R. Munkittrick \& G. V.D. Kraak. 2001. Recovery of ovary size, follicle cell apoptosis, and HSP70 expression in fish exposed to bleached pulp mill effluent. Canadian Journal of Fisheries and Aquatic Sciences, 58: 620-625. 
Lima-Junior, S. E. \& R. Goitein. 2006. Condition factor and gonadal cycle of females of Pimelodus maculatus (Osteichthyes, Pimelodidae) in Piracicaba River (SP, Brazil). Boletim do Instituto de Pesca, 32: 87-94.

Lundberg, J. G. \& M. W. Littmann. 2003. Pimelodidae (longwhiskered catfishes). Pp. 432-446. In: Reis, R. E., S. O. Kullander \& C. J. Ferraris Jr. (Eds.). Checklist of the freshwater fishes of South and Central America. Porto Alegre, Edipucrs.

Maia, B. P., S. M. F. Ribeiro, P. M. Bizzotto, V. Vono \& H. P. Godinho. 2007. Reproductive activity and recruitment of the yellow-mandi Pimelodus maculatus (Teleostei: Pimelodidae) in the Igarapava Reservoir, Grande River, Southeast Brazil. Neotropical Ichthyology, 5: 147-152.

Mazzoldi, C., C. W. Petersen \& M. B. Rasotto. 2005. The influence of mating system on seminal vesicle variability among gobies (Teleostei, Gobiidae). Journal of Zoology Systematic and Evolutionary Research, 43: 307-314.

Melo, R. M. C., F. P. Arantes, Y. Sato, J. E. Santos, E. Rizzo \& N. Bazzoli. 2011. Comparative morphology of gonadal structure related to reproductive strategies in six species of Neotropical catfishes (Teleostei: Siluriformes). Journal of Morphology, 272: 525-535.

Olden, J. D. \& R. J. Naiman. 2010. Incorporating thermal regimes into environmental flows assessments: modifying dam operations to restore freshwater ecosystem integrity. Freshwater Biology, 55: 172-182.

Parenti, L. R. \& H. J. Grier. 2004. Evolution and phylogeny of gonadal morphology in bony fishes. Integrative Comparative Biology, 44: 333-348.

Parkinson, D., J. C. Philippart \& E. Baras. 1999. A preliminary investigation of spawning migrations of grayling in a small stream as determined by ratio-tracking. Journal of Fish Biology, 55: 172-182.

Paukert, C. \& R. S. Rogers. 2004. Factors affecting condition of Flannelmouth Suckers in the Colorado River, Grand Canyon, Arizona. North American Journal of Fisheries Management, 24: 648-653.

Rizzo, E., Y. Sato, B. P. Barreto \& H. P. Godinho. 2002. Adhesiveness and surface patterns of eggs in neotropical freshwaters teleosts. Journal of Fish Biology, 61: 615-632.
Rizzo, E., H. P. Godinho \& Y. Sato. 2003. Short-term storage of oocytes from the neotropical teleost fish Prochilodus marggravii. Theriogenelogy, 60: 1059-1070.

Ruane, R. J., C. E. Bohac, W. R. Seawell \& R. M. Shane. 1986. Improving the downstream environment by dam release modifications, Pp. 270-277. In: Hall, G. E. \& van den Avyle (Eds.). Reservoir fisheries management: strategies for 80's. Bethesda: American Fisheries Society.

Santos, J. E., N. Bazzoli, E. Rizzo \& G. B. Santos. 2004. Reproduction of the catfish Iheringichthys labrosus (Lutken) (Pisces, Siluriformes). Revista Brasileira de Zoologia, 21: 193200.

Sato, Y., N. Bazzoli, E. Rizzo, M. B. Boschi \& M. O. T. Miranda. 2003. Impacto do reservatório de Três Marias sobre a piracema de Prochilodus argenteus no rio São Francisco, a jusante da usina hidrelétrica. Pp. 327-345. In: Godinho, H. P. \& A. L. Godinho (Eds.). Águas, peixes e pesca no rio São Francisco das Minas Gerais. Belo Horizonte, MG. PUC Minas.

Sato, Y., N. Bazzoli, E. Rizzo, M. B. Boschi \& M. O. T. Miranda. 2005. Influence of the Abaeté River on the reproductive success of the neotropical migratory teleost Prochilodus argenteus in the São Francisco River, downstream from the Três Marias dam, southeastern Brazil. River Research and Applications, 21: 939-950.

Todd, C. R., T. Ryan, S. J. Nicol \& A. R. Bearlin. 2005. The impact of cold water releases on the critical period of post-spawning survival and its implications for Murray cod (Maccullochella peelii peelii): a case study of Mitta Mitta River, southeastern Australia. River Research and Applications, 21: 1035-1052.

Weber, L. P., Y. Kiparissis, G. S. Hwang, A. J. Niimi, D. M. Janz \& C. D. Metcalfe. 2002. Increased cellular apoptosis after chronic aqueous exposure to nonylphenol and quercetin in adult medaka (Oryzias latipes). Comparative Biochemistry and Physiology Part C, 131: 51-59.

Welcome, R. L. 1979. Fisheries ecology of floodplain rivers. New York: Longman.

Submitted March 20, 2013

Accepted July 8, 2013 by Clarice Fialho Published September 30, 2013 